\title{
O SOM DA VIOLA “INVOCANO” UM SENTIMENTO TOPOFÍLICO CAIPIRA
}

\author{
The sound of brasilian ten strings guitar invoking a topophilic feeling hick
}

Denis Rilk Malaquias*

*Doutor em Geografia pelo PPGeo/UFG - denisrmalaquias@gmail.com

Recebido em 20/06/2019. Aceito para publicação em 30/07/2019.

Versão online publicada em 10/09/2019 (http://seer.ufrgs.br/paraonde)

\begin{abstract}
Resumo:
É habitual alguém ouvir o som de uma viola ponteando e sua imaginação se remeter instantaneamente a imagens do campo em sua mente, especialmente para aqueles que tiverem alguma vivência rural. $E$, não por acaso, o lugar vivenciado pelo caipira sempre foi memorado com certo afeto nas suas canções. Para tentarmos entender esse apreço do cancioneiro caipira pelo seu sertão, utilizaremos ferramentas baseadas numa perspectiva geográfica para analisar essa afeição do caipira pelo seu lugar, esse sentimento é denominado por Tuan (1980) como topofilia. Mesmo entre aqueles personagens urbanos que de uma forma ou de outra se encantaram com o som da viola e tomaram o instrumento como bandeira, o sentimento topofílico caipira desses violeiros pode ser percebido na vida e obra dos mesmos, nas variadas narrativas acompanhadas ao som da viola.
\end{abstract}

Palavras-chave: Música Caipira; Viola Caipira; Sentimento Topofílico.

\begin{abstract}
:
It is customary for someone to hear the sound of a brazilian ten guitar playing and his imagination instantly relate to the field in his mind, especially for those who have some rural experience. And, not by chance, the place experienced by the caipira was always remembered with a certain affection in his songs. In order to try to understand this appreciation of the caipira cancioneiro by its backlands, we will use tools based on a geographic perspective to analyze this affection of the caipira by its place, that feeling is denominated by Tuan (1980) like topophilia. Even among those urban characters who, in one way or another, were enchanted by the sound of the brazilian ten guitar and took the instrument as a flag, the feeling of these violeiros can be perceived in their life and work, in the varied narratives accompanied to the sound of the brazilian ten guitar.
\end{abstract}

Key-words: Caipira Music; Brasilian Ten Guitar; Topophilic Sentiment.

\section{Introdução}

Antes de discorrermos sobre as questões de afetividade espacial, se faz necessário ter uma noção sobre o conceito de lugar, uma referência espacial pela qual sentimentos são evidenciados. As definições dessa palavra extrapolam a ideia de localização, essa que pode ser definida através de apontamentos de latitude e longitude. O lugar é consubstanciado através da experienciação, onde o ser humano estabelece valores (positivos ou negativos), significações e conexões. Conforme Oliveira (2012):

As dimensões significativas do lugar, [...] são pensadas em termos geográficos a partir da experiência, do habitar, do falar e dos ritmos e transformações. É o lugar 
experienciado como aconchego que levamos dentro de nós. Ou o lugar consciente do tempo social histórico, recorrente e mutável, no transcorrer das horas do tempo em um espaço sentido dentro de um lugar interior ou exterior (Ibidem, p. 16).

Não é incomum entre alguns grupos e sociedades, até mesmo em meio aqueles de áreas que possuem certa dificuldade de sobrevivência, os indivíduos residentes adquirirem certa afeição pelo lugar da sua naturalidade, da sua convivência ou de sua moradia, uma afeição pelo terreno. Segundo Oliveira (2012, p. 12) "conhecer um lugar é desenvolver um sentimento topofílico ou topofóbico. Não importa se é um local natural ou construído, a pessoa se liga ao lugar quando este adquire um significado mais profundo ou mais íntimo". O caipira, personagem da região centro-sudeste também demonstra estar bem vinculado afetivamente a sua terra, ou seu lugar. Não é à toa que as possíveis origens etimológicas da palavra "caipira" apontam para sua ligação com a terra, o mato. Conforme aponta Sousa (2005, p.21) "a raiz dessa palavra, caí, significa o gesto do macaco escondendo o rosto. Ela aparece em capipiara, "o que é do mato", e em capiã, "dentro do mato". Enfim, aparece em caapi, 'trabalhador na terra' e em caapiára, lavrador'. Donde, enfim, redundaria em 'caipira'”. É muito comum um caipira, que de tão ligado com a terra, com o seu lugar, até mesmo protelar sua ida à cidade para repor suprimentos e insumos dos quais não é produzido na terra através das atividades agropecuárias e ou de forma extrativista.

Essa afeição do caipira pelo seu lugar é explicitamente declarada, seja nas suas declarações e exposições verbais, nas suas obras, manifestações artísticas, e na manutenção das festas e tradições folclóricas onde a temática do seu lugar é venerada. Enfim, as manifestações culturais do caipira, de uma forma ou de outra, generalizadamente, sempre acaba apontando para o apreço do caipira para com o seu lugar de convívio e todas as práticas envolvidas nesse contexto. Na música do caipira não podia ser diferente.

\begin{abstract}
Os elementos principais de que se constitui o imaginário da música caipira estão relacionados a um lugar determinado, com a cena principal em que se desenvolve toda a ação. Esse espaço pode estar localizado na terra da própria família ou na propriedade de outrem. [...] Desse modo, a vida social do caipira está centrada sobre a família e sobre o lugar em que fixa residência. Em torno desse núcleo é que vão sendo apresentados os demais elementos que, em conjunto, constituirão o imaginário do "pequeno agricultor", "pequeno sitiante", "pequeno lavrador" ou simplesmente caipira: o terreiro da casa com seus pequenos animais e aves, o monjolo, a biquinha, o rego d'água, o cavalo selado para as pequenas viagens ali mesmo nas redondezas do seu bairro rural, a igrejinha e seu sino, a viola, a catira, a folia de reis, os casos de assombração, os respeito às interdições, o temor à polícia e tudo o mais que constrange o ímpeto de sair dos estritos limites da casa e da família (PIMENTEL, 1997, p. 209).
\end{abstract}

Esse elo afetivo do caipira com o seu lugar é enfatizado constantemente nas letras de suas canções. Como na composição de Carreirinho, Rincão de Minha Terra, onde o protagonista, que é nascido no "pé de uma serra" no município de Bofete, São Paulo, narra as peculiaridades do seu dia a dia no campo, as características da natureza do lugar, suas obrigações com o trabalho no campo, a lida com o gado, as caçadas e etc. Que por fim, por algum motivo, resolve se mudar para a cidade e a partir daí vive uma vida de lamentações. Como é bem enfatizado nos versos da última estrofe: Depois resolvi me mudar pra cidade / Hoje eu passo aqui grandes contrariedades /Eu canto 
assim e vivo a cantar / Só para enganar esta grande saudade. Esse tipo de lamúria também pode ser observado na moda de viola Cabocla Tereza de Nhô Chico e Dino Franco; na música Fogão de Lenha composta por Carlos Colla, Maurício Duboc e Xororó; no pagode de viola Minas Gerais de Tião Carreiro e Lourival dos Santos, dentre várias outras canções caipiras.

É comum também composições usando como pontos de referência certo elementos da flora, como é o caso da canção Pé-de-cedro composta por Goiá e Zacarias Mourão, onde na narrativa, o personagem planta uma muda dessa árvore no seu quintal em Coxim no estado do Mato Grosso, hoje Mato Grosso do Sul, e esse indivíduo por algum motivo tem que partir desse lugar, e passa 20 anos desejando voltar, e fazendo prece para Virgem Santa que o fim da sua vida seja ali, e que seu desejo é ser enterrado à sombra dessa árvore. Esse personagem até se comove ao sanar sua saudade de retornar a esse lugar, a ponto de quase chorar ao chegar e rever esse Pé-de-cedro crescido.

\section{Pé-de-cedro}

Foi num belo Matogrosso há vinte anos atrás

Naqueles tempos queridos que não voltam nunca mais

Nas matas onde eu passava um pequeno arbusto achei

Levando pra minha casa no meu quintal plantei

Era um belo pé de cedro, pequenino, em formação

Sepultei suas raízes na terra fofa do chão

Um dia parti pra longe, amei, também sofri

Vinte anos se passaram em que distante eu vivi

"À Virgem Santa sagrada uma prece eu vou fazer Junto ao meu pé de cedro é que desejo morrer Quero ter sua sombra amiga projetada sobre mim No meu último repouso na cidade de Coxim"

Hoje volto arrependido para o meu antigo lar Abatido e comovido, com vontade de chorar E rever meu pé de cedro que está grande como o quê Mas é menor que a saudade que eu sinto de você

Cresceu como minha mágoa, cresceu numa força rara Mas é menor que a saudade que até hoje nos separa A terra ficou molhada do pranto que derramei

Que saudade, pé de cedro, do tempo que eu te plantei

O contentamento por se ter à disposição recursos fluviais como um rio, uma lagoa e etc., um ambiente em que pratica suas atividades de pesca, seja para lazer ou para subsistência, as práticas nesses ambientes são sempre narradas como algo de bom grado. O abastecimento de água é essencial para as atividades agropecuárias do caipira, seja para irrigação no cultivo de lavouras ou até mesmo para suprir a sede dos rebanhos. Quando o caipira está provido dessa fartura hídrica no seu pedaço de terra, seu apreço pelo lugar acaba sendo ainda maior, a ponto de pensar que tem tudo que precisa no seu lugar, inclusive a inspiração para se compor ao som da viola. Os versos 
da canção Três Nascentes composta por João Pacífico faz alusão a esse deleite.

\section{Três Nascentes}

Tenho o sol que nasce por detrás do morro

Dá bom dia ao galo primeiro a despertar

O sol aquece o pasto, o sereno corta

Abro a minha porta e vou trabalhar

Tenho uma nascente que vem lá da serra

Toca meu moinho toca meu monjolo

Enche a lagoa pra molhar a horta

Sento em minha porta vejo florescer

Tenho a lua branca nasce com as estrelas

llumina a mata borda todo o céu

Nasce o som da viola tudo me conforta

Fecho a minha porta e sonho com você.

São várias as temáticas de composições na música caipira que aludem a esse elo afetivo com o lugar, em muitos dos casos algo é usado para representar simbolicamente o referencial do lugar. Algo que vem à tona quando se lembra do lugar, que tem uma importância pra sua vida, por ter ocorrido algum fato importante da sua vida frente aquele "objeto" e que o faz refletir, faz sentir saudades, algo que faz aflorar a paixão desse caipira por algum lugar, pelo seu modo de vida presente ou abandonado por força maior. Mas talvez a letra de canção caipira que melhor representa e enfatiza o apreço do caipira pelo seu lugar seja a canção Saudade da Minha Terra composta por Goiá.

\section{Saudade da Minha Terra}

De que me adianta viver na cidade Se a felicidade não me acompanhar Adeus, paulistinha do meu coração Lá pro meu sertão, eu quero voltar Ver a madrugada, quando a passarada Fazendo alvorada, começa a cantar Com satisfação, arreio o burrão Cortando estradão, saio a galopar E vou escutando o gado berrando Sabiá cantando no jequitibá

Por Nossa Senhora, Meu sertão querido Vivo arrependido por ter deixado Esta nova vida aqui na cidade De tanta saudade, eu tenho chorado Aqui tem alguém, diz que me quer bem Mas não me convém, eu tenho pensado Eu fico com pena, mas esta morena não sabe o sistema que eu fui criado Tô aqui cantando, de longe escutando Alguém está chorando, com rádio ligado 
Que saudade imensa do campo e do mato

Do manso regato que corta as Campinas

Aos domingos ia passear de canoa

Nas lindas lagoas de águas cristalinas

Que doce lembrança daquelas festanças

Onde tinham danças e lindas meninas

Eu vivo hoje em dia sem Ter alegria

O mundo judia, mas também ensina

Estou contrariado, mas não derrotado

Eu sou bem guiado pelas mãos divinas

Pra minha mãezinha já telegrafei

E já me cansei de tanto sofrer

Nesta madrugada estarei de partida

Pra terra querida que me viu nascer

Já ouço sonhando o galo cantando

O inhambu piando no escurecer

A lua prateada clareando as estradas

A relva molhada desde o anoitecer

Eu preciso ir pra ver tudo ali

Foi lá que nasci, lá quero morrer

O personagem narrado na letra dessa música é o próprio compositor, Gerson Coutinho da Silva, o Goiá. Nascido em Coromandel, Minas Gerais, ainda jovem mudouse de sua terra natal para tentar investir na sua carreira artística, mudou-se primeiro para Goiânia. Goiá sempre foi ligado afetivamente a sua terra natal - há relatos que nunca passou muito tempo sem visitá-la - mas, foi quando partiu para grande São Paulo em busca de melhores oportunidades para carreira artística que o sentimento de saudade do seu lugar foi agravado. Goiá sempre escrevia para sua mãe, esta que, inclusive, seria a personagem descrita nos versos "Tô aqui cantando, de longe escutando / Alguém está chorando, com rádio ligado". Sua mãe sempre acompanhava a carreira do seu filho e sempre atenta às suas aparições no rádio. Segundo Brito (2009, p. 33-34):

Os dois primeiros versos da canção talvez sejam os mais presentes na memória dos fãs: o dia qualquer de 1953 em que Goiá foi em busca do sonho: ser um artista. O apoio materno e sua determinação de enfrentar o sofrimento que era saber que sua mãe chorava quando ouvia cantar nos programas de rádio são um ponto comum na lembrança de quem cultua a memória do artista. A saudade da mãe foi tem de outros sucessos: Meu natal, sem mamãe e Saudade da minha terra (Tô aqui cantando, de longe escutando, / alguém está chorando com o rádio ligado). Assim, Goiá registrava na música mais um momento de sua carreira que julgava relevante.

Poderíamos até pensar que é um tipo de sentimento presente em outros tempos, outras fases da música caipira e que no mundo contemporâneo esse elo afetivo do caipira com o lugar estaria defasado, as canções não expressariam esse tipo de sentimento. Contudo, apesar de as gravações modernas do chamado sertanejo serem bem mais focadas no consumo em massa, no comércio, do que a música caipira raiz, até nesse segmento, e na atualidade podemos notar músicas que retratam essa temática. Como é o caso da canção Deus e Eu no Sertão composição de Victor Chaves e lançada em 2009 pela dupla Victor e Leo (ambos naturais de Ponte Nova, Minas Gerais) como trilha sonora para a novela paraíso. Os primeiros versos da canção, "Nunca vi ninguém viver tão feliz / Como eu no sertão", além de representar bem o elo afetivo com o lugar, o sertão, ficou impregnado na mente dos brasileiros por conta da 
trilha da novela e o sucesso da dupla na ocasião. Outro contemporâneo que demonstra esse tipo de sentimento pelo seu lugar é cantor Daniel, que apesar de ter tido maior evidência na mídia na década de 1990 com a dupla João Paulo e Daniel, continua em plena atividade. Declara o músico:

\begin{abstract}
Eu nasci em Brotas (SP), amo essa terra, não consigo me desvincular daqui. As pessoas me questionam se não seria mais fácil morar em São Paulo. Pra mim, não. Preciso da energia que esse lugar emana. É onde eu consigo recarregar minhas baterias, o meu porto seguro. Quero ter a possibilidade de que meus filhos sejam criados aqui. Tudo é muito imprevisível ainda, mas quero que eles tenham essa oportunidade que eu tive. Sair daqui, jamais. Pessoas que faziam parte da minha vida, da minha história, fazem parte até hoje do meu cotidiano. O Brasil tem várias regiões que propagam a tal música de raiz, a música do campo. No meu ponto de vista, o que me deu esse contato foi a família. Minha família é muito raiz, da roça mesmo (TELÓ; PIUNTI, 2015, p.49).
\end{abstract}

Um outro exemplo mais recente de apreço por esse tipo ambiente bucólico memorado pelo caipira de outrora está na composição Vivendo Aqui No Mato, lançada em 2017 pelo Trio Parada Dura, no álbum Chalana, Churrasco e Viola, o solo da introdução da música tem ponteios de viola caipira apoiado pelo som de um violino. Quem assina a autoria dessa é a dupla Zé Neto \& Cristiano, ambos naturais de São José do Rio Preto, São Paulo, os quais fazem também uma participação especial na interpretação dessa música no DVD do trio.

\title{
Vivendo Aqui No Mato
}

Não troco seu despertador pelo cantar do galo

Não troco seu carro bonito pelo meu cavalo

Não troco seu ar poluído pelo pó da estrada

Aqui não tem trânsito só tem boiada

Nosso céu é limpo e a noite enluarada

Aqui o nosso alimento é a gente que faz

Plantamos de tudo pro gasto e um pouco mais

E se vier fazer visita aí que a gente gosta

Moda de viola, uma boa prosa

Em volta da fogueira então, a gente mostra

O meu amanhecer tem o cantar do galo

O cheiro do mato com gota de orvalho

E é tão gostoso beber um café olhando o sol nascer

Pego meu cavalo e saio pelo pasto

Toco meu berrante apartando o gado

Sei que sou caipira, mas vivo melhor

Morando aqui no mato

A mensagem transmitida no texto dessa música (bem com os elementos sonoros, inclusive, a matriz rítmica sobre a qual foi estruturada é uma guarânia), notadamente, é de alguém que teve certa experiência no meio rural e possui uma grande afeição por esse tipo de vida campesina. O curioso é que foi composta por uma dupla de sertanejos universitários, que teve sua carreira profissional iniciada no ano de 2011, um estilo bem diferente da proposta da composição. Poderia até ser esse o motivo da dupla ter cedido 
a música para ser gravada pelo Trio Parada Dura ao invés de lançá-la em um álbum próprio. Ou mesmo por questões contratuais, uma vez que são contratados pela Workshow (sede em Goiânia), e a maior parte do repertorio dos artistas que assinam contrato com esse escritório são no estilo mais contemporâneo do sertanejo universitário. Mas é fato que, Zé Neto \& Cristiano vivenciaram a cultura musical caipira e o meio rural, bem como existe uma profunda relação afetiva com os mesmos. Segundo informações da página ${ }^{1}$ oficial da dupla na internet, eles foram criados na zona rural, divisa de Ipiguá com São José do Rio Preto, São Paulo, são amigos desde a infância, e influenciados pelas famílias, sempre estiveram envolvidos com a música sertaneja raiz e também religiosa.

\title{
2 Topofilia: considerações sobre o tema
}

Antes de aprofundarmos no assunto, e tentarmos entender esse apreço do cancioneiro caipira pelo seu sertão, utilizaremos ferramentas baseadas numa perspectiva geográfica para essa análise sobre o que pode ser entendido nessa afeição pelo lugar. Vale ressaltar que desde cedo, a palavra "sertão" foi usada pelos compositores de música caipira como apenas mais uma forma de referir-se ao que estava fora da cidade (PIMENTEL, 1997, p. 219). Como ponto de partida tomaremos a consideração de Castrogiovanni (2007), em que o mesmo alega que:

\begin{abstract}
O estudo do espaço geográfico deve considerar as noções e os conceitos, já construídos, que envolvam a espacialidade e valorizar a formação da consciência territorial- o sentimento de pertencer ao lugar, tão comumente adormecido em países como o Brasil. Deve interpretar as territorialidades dentro da complexidade e conhecer não apenas os elementos objetivos que compõem o espaço, mas valorizar as subjetividades e tentar entendê-las (Ibidem, p. 41).
\end{abstract}

Em se tratando de afeição pelo "lugar", um conceito que tem sido discutido em trabalhos, especialmente geográficos - grande parte desses abordam questões culturais -, e que naturalmente vem à tona como essencial para esse tipo de análise, é o conceito de topofilia. Em português diríamos topofilia, resultado da contração da palavra grega topos que exprime o lugar, e filia do grego phílos que indica noções de afeição, gosto ou amizade (BORGES, 2013, p.105). Face ao exposto anteriormente, nos remetemos aos seguintes questionamentos: Esse elo afetivo entre esses violeiros e os territórios foi influenciado pelo seu fazer musical ligado à cultura caipira? O fato de terem nascido em áreas onde essa cultura é mais difundida propiciou esse sentimento de apego ao lugar? Como é evidenciado esse sentimento? Para essa análise usaremos as reflexões de Tuan (1980) sobre topofilia. Segundo esse autor:

A palavra "topofilia" é um neologismo, útil quando pode ser definida em sentido amplo, incluindo todos os laços afetivos dos seres humanos com o meio ambiente material. Estes diferem profundamente em intensidade, sutileza e modo de expressão. A resposta ao meio ambiente pode ser basicamente estética: em seguida, pode variar do efêmero, prazer que se tem de uma vista, até a sensação de beleza, igualmente fugaz, mas muito mais intensa, que é subitamente revelada. A resposta pode ser tátil: o deleite ao sentir o ar, água, terra. Mais permanentes e mais difíceis

${ }^{1}$ Disponível em: <http://www.zenetoecristiano.com.br/historia> acesso dia 19 de fevereiro de 2019. 
de expressar, são os sentimentos que temos para com um lugar, por ser o lar, o locus de reminiscências e o meio de se ganhar a vida (Ibidem p.107).

O pioneiro na utilização do termo foi o filósofo e poeta francês Gaston Bachelard no livro La poétique de l'espace em 1957. Esse trabalho que serviu de referência para vários outros autores, inclusive o geógrafo Yi-Fu Tuan, que hoje é uma grande referência no tema. Bachelard (2008, p.19) apresenta o termo já no prólogo de seu livro e elucida:

\begin{abstract}
No presente livro, nosso campo de exame tem a vantagem de ser bem delimitado. Isso porque pretendemos examinar imagens bem simples, as imagens do espaço feliz. Nessa perspectiva, nossas investigações mereceriam o nome de topofilia. Visam determinar o valor humano dos espaços de posse, dos espaços defendidos contra forças adversas, dos espaços amados. Por razões não raro muito diversas e com as diferenças que as nuanças poéticas comportam, são espaços louvados. Ao seu valor de proteção, que pode ser positivo, ligam-se também valores imaginados, e que logo se tornam dominantes. O espaço percebido pela imaginação não pode ser o espaço indiferente entregue à mensuração e à reflexão do geômetra. É um espaço vivido. E vivido não em sua positividade, mas com todas as parcialidades da imaginação. Em especial, quase sempre ele atrai. (BACHELARD, 2008, p. 19).
\end{abstract}

O singular é que esse tipo de espaço percebido pela imaginação do qual refere Bachelard nesse trecho, se assemelha muito com os das narrativas das canções caipiras. Nem sempre é algo mensurável e ou "palpável", relatam do vivido, do experienciado, do real reminiscente de alguma ocasião da vida dos protagonistas das narrativas dessas canções. Mas que também pode ocorrer de fazer uma alusão a elementos presentes no contexto de um espaço imaginário idealizado. Contudo, mesmo se tratando de uma contextura fictícia de uma canção, é possível perceber nessas, a ênfase a elementos do ambiente (que às vezes são usados como ponto referencial) que evidenciam a afeição pelo lugar. Tuan (1980) dialoga com esse autor quando aponta que:

\begin{abstract}
Certos ambientes naturais têm figurado de maneira proeminente nos sonhos da humanidade de um mundo ideal: a floresta, a praia, o vale e a ilha. A construção do mundo ideal é uma questão de remover os defeitos do mundo real. A geografia fornece necessariamente o conteúdo do sentimento topofílico. Os paraísos têm uma certa semelhança familiar porque os excessos da geografia (muito quente ou muito frio, muito úmido ou muito seco) são removidos. Em todos eles abundam as plantas e animais úteis e amigos do homem. Os paraísos também diferem em suas respectivas excelências: alguns são abundantes, outros são florestas mágicas, ilhas perfumadas ou montanhas (Ibidem, p. 286).
\end{abstract}

Esse modelo de paraíso ao qual descreve Tuan, e que, baseado na consideração anterior de Bachelard, o que ele desencadeia na imaginação e emoção não pode ser medido, mas é um espaço que atrai por conta de suas particularidades. Incita um sentimento onde tudo ali é na medida e organizado dentro desse espaço específico. Isso pode ser notado nos versos da canção Jeitão de Caboclo, composta por Valdemar Reis e Liu. Esse ambiente do qual o narrador faz uma retrospectiva nostálgica, é de uma completude singular. Acrescendo ou retirando algo, desarmonizaria esse ciclo perfeito de eventos no cotidiano do paraíso. As águas do ribeirão além de cristalinas e marcantes, também têm seu proveito no trabalho diário de beneficiamento de alimentos. 
A fauna do lugar é marcante, e os seus integrantes até parecem interagirem de forma orquestrada, onde cada naipe de animais tem um lugar definido no palco, e seria esse sítio/paraíso esse palco. Elementos da flora também podem ser marcantes, uma simples planta pode fazer o lugar reacender na memória do indivíduo. Algo corriqueiro como sentir o cheiro de uma flor pode remeter suas lembranças ao lugar, reacendendo o sentimento de apego.

\author{
Jeitão de Caboclo \\ Se eu pudesse voltar, Ao meu tempo de criança. \\ Ao meu tempo de criança, Reviver a juventude. \\ Com muita perseverança \\ Morar de novo no sítio, Na casa de alvenaria. \\ Ver passarinhos cantando, Quando vem rompendo o dia. \\ Eu voltaria rever, O pé de manjericão. \\ A corroira cantando, Lá no oco do mourão. \\ Os bezerros no piquete, E as nossas vacas leiteiras. \\ E papai tirando leite, Bem cedinho na mangueira. \\ Eu voltaria rever, O ribeirão taquari. \\ Com suas águas bem claras, onde pesquei lambari. \\ $O$ velho carro de boi, O monjolo e a moenda. \\ As vacas Maria preta, A tirolesa e a prenda. \\ $\mathrm{Na}$ varanda tábua grande, Cheia de queijo curado. \\ E mamãe assando pão, No forno de lenha ao lado. \\ Nossa reserva de mato, Linda floresta fechada. \\ A trilha funda do gado, Retalhando a invernada. \\ Iria rever o sol, Com seus raios florescentes. \\ Escondendo atrás da serra, levando o dia da gente. \\ O pé de dama da noite, Junto ao mastro de são João. \\ Que até hoje perfuma, A minha imaginação. \\ O caso é que eu não posso Fazer o tempo voltar. \\ Sou um carro sem chumaço, Que já não pode cantar. \\ Vou vivendo na cidade, Perdendo as forças aos poucos. \\ Mas não consigo perder, O meu jeitão de caboclo.
}

Todo um espaço-tempo não mais existente é rememorado na letra da canção: afazeres, festas, construções, utensílios, animais. Mas houve e há desigualdade no campo. A harmonia que alguns poetas e compositores traçam, outros poetas e compositores podem fazer crítica, como as canções caipiras que distinguem a vida de ricos e pobres. No campo há violência, tema que raramente aparece nas canções ditas caipiras. Não é tão comum a participação de caipiras em enfrentamentos e ou protestos políticos como ocorre entre os artistas da chamada MPB, salvo algumas exceções, mas é muito comum essa temática ser abordada de forma bem humorada, como é o caso da "dupla Jararaca e Ratinho no Rio de Janeiro que passou a fazer teatro de revista em 1929. A apresentação da dupla caipira ia das melodias e canções sertanejas às piadas, e, principalmente, às críticas e sátiras políticas" (CONTIER, 2003, p. 110). Percebemos que esse tipo de discurso tem maior evidência na parte de "contação" de causos ocorrentes nas apresentações do que as próprias canções. A temática do texto tende a influenciar a estética musical da canção caipira. Geralmente as modas e os ritmos mais arrastados tendem a serem mais introspectivos e reflexivos, trazendo mensagens de "lições de moral", saudades e etc. por sua vez, os ritmos de andamentos mais 
acelerados tendem a ter temáticas mais alegres e bem humoradas, com sátiras, saudosismos e etc.

O cancioneiro caipira, apesar de possuir canções com narrativas de eventos tristes e ou trágicos ${ }^{2}$ lamúria por um desamor e etc. em sua maioria, quando faz menção a reminiscências de um lugar vivido, tende a expor uma visão mais positiva do mesmo, dando ênfase a elementos que, sem um olhar poético, talvez não daria tamanha importância. Uma das características do caipira (o que não se aplica àquele caipira contemporâneo e/ou ao denominado sertanejo que está acomodado aos confortos da vida moderna, que possui na sua casa, eletrodomésticos, luz elétrica, que ostenta com automóveis de luxo e ou outros bens materiais) é a cultura do mínimo, a subsistência (CÂNDIDO, 2001), isso talvez seja um dos motivos da valoração das minúcias do lugar em suas canções. Tuan alerta que:

O meio ambiente pode não ser a causa direta da topofilia, mas fornece o estímulo sensorial que, ao agir com a imagem percebida, dá forma as nossas alegrias e ideais. [...] aquilo que decidimos prestar atenção (valorizar ou amar) é um acidente do temperamento individual, do propósito e das forças culturais que atuam em determinada época (TUAN, 1980, p. 129).

Este quadro talvez possa explicar o fato desse tipo de temática ter maior ênfase e presença nas canções "caipira raiz", que tiveram maior predomínio antes da década de 1970. Este é o período em que o país se urbaniza, em que Rio de Janeiro e São Paulo e outras cidades se tornam metrópoles, em que Brasília é construída e cresce num movimento que se confronta mais ainda com o interior do país. Antes do chamado "sertanejo romântico" invadir de forma massiva no espaço que antes prevalecia o caipira, e, ainda extrapolar esse espaço conquistando um novo público, agora, talvez um pouco mais ligado a ambientes mais urbanizados. Práticas culturais em que outrora o caipira tinha maior ligação com o cotidiano do campo, agora mudaria a temática e estaria lamentando nos bares os desamores ocorridos nas periferias da cidade com o novo sertanejo. "As imagens mudam à medida que as pessoas adquirem novos interesses e poder" (TUAN, 1980, p.137).

Segundo Gómez (2001, p. 27) "os lugares são espaços de relação mais íntima entre a natureza construída, as relações sociais e as significações culturais”. Ainda em relação ao conceito de "lugar", se levarmos em consideração também as ponderações de Tuan, poderíamos entender o mesmo como um "recinto" provedor, dotado de funcionalidades. "Os lugares são centros aos quais atribuímos valor e onde são satisfeitas as necessidades biológicas de comida, água, descanso e procriação (TUAN, 2013, p. 12)". Além das interações espaciais atreladas às representações socioculturais, todas essas "provisões" são notadamente encontradas pelo caipira em seu recinto de vivência, especialmente aquele que ainda reside no campo e retira do pedaço de terra elementos essenciais para subsistência como água (usada para o plantio, criação de gado e consumo próprio) e alimentos obtidos através do plantio e colheita e a criação de animais. "O lugar é um mundo de significado organizado. É essencialmente um conceito

\footnotetext{
${ }^{2}$ Como no caso da canção Menino da Porteira (Teddy Vieira / Luizinho), ao saber da notícia da tragédia ocorrida, que veio levar a óbito, o garoto que abria a porteira para passagem das comitivas boiadeiras no município de Ouro Fino, o personagem boiadeiro, parece desenvolver um sentimento negativo em relação ao local da porteira, chegando ao ponto de fazer juramento que nunca mais tocaria berrante (vale ressaltar que o som produzido pelo berrante é de suma importância na condução e orientação do trajeto do gado nas comitivas) naquele "pedaço de chão", esse sentimento negativo pelo o lugar nos remete também a noção de topofobia (TUAN, 1980).
} 
estático. Se víssemos o mundo como processo, em constante mudança, não seríamos capazes de desenvolver nenhum sentido de lugar" (Ibidem, p. 219). Justificando a aplicabilidade para análise dessas relações de lugar no contexto musical, podemos citar Dozena (2016), onde o mesmo alega que:

\begin{abstract}
Musicalidade pode ser trazida ancestralmente pelas coletividades, atendendo não somente às vontades de reprodução material e às necessidades de sobrevivência, mas também expressando muitas especificidades culturais que efetivamente mobilizam e animam os agrupamentos sociais; ao mesmo tempo em que revelam uma história não-oficial que passa a ser contada pelas ruas e áreas diversas das cidades brasileiras. As músicas contribuem para a criação de uma ligação emotiva e humana com os lugares, além de demarcarem corporeidades, territorialidades e relações sócio espaciais; sendo produzidas a partir de estímulos colocados pelos lugares e por isso mesmo evidenciando o sentido desses lugares (Ibidem, p. 377).
\end{abstract}

Parece existir também certa subjetividade na ideia de lugar, os valores, que nesse caso seriam simbólicos, possuem representações diferentes, na medida em que é vivenciado por indivíduos de diferentes formas. Através da experiência com o lugar, cada indivíduo interage com as funcionalidades que the são mais convenientes. Essas diferentes interações produzem diferentes acepções de valores em relação ao lugar, estes que nem sempre são possíveis de ter descrições concretas. Essa noção de valor do lugar também tende a se manifestar quando há uma ameaça a algum tipo de "patrimônio" existente no local.

\title{
3 Os "neovioleiros" e a afeição pelo território caipira
}

É habitual alguém ouvir o som da viola ponteando e sua imaginação nos remetermos instantaneamente a imagens do campo em sua mente, especialmente para aqueles que tiverem alguma vivência rural. O mesmo pode acontecer com quem tem o conhecimento da cultura caipira e da identidade sonora que esse instrumento enfatiza, pois, apesar dele estar presente em outras culturas, ligar o som da viola ao contexto caipira não é algo inusitado. Assim como o elo afetivo do caipira com seu pedaço de terra ou ambiente de convívio e vivência no campo. O que podemos designar aqui baseado nas reflexões de Tuan (1980) de sentimento topofílico caipira. Esse sentimento, no âmbito da música caipira, não é algo exclusivo somente das letras de canções. Em declarações pessoais de artistas caipiras (tanto os de estilos mais contemporâneos quanto os mais tradicionais), sobretudo violeiros, fica bastante evidenciado também um entusiasmo pela área geográfica onde predomina sua cultura. Os chamados violeiros neocaipiras destacam-se, sobretudo, pelo seu trabalho com a música instrumental de viola, explorando os mais variados estilos e possibilidades no instrumento. E esse percurso da viola instrumental no mercado fonográfico tem seu marco na década de 1960, conforme resume bem João Afonso da Silva no prólogo do livro Viola caipira instrumental: 42 estudos progressivos de Rui Torneze:

Vai longe o ano de 1963, em que Theodoro Nogueira publicou em A Gazeta suas anotações para um estudo de viola, ao mesmo tempo em que preparou seus alunos, depois famosos violonistas, Barbosa Lima e Geraldo Ribeiro, para gravarem, respectivamente, "Viola Brasileira" e suas transcrições: "Bach na viola brasileira", 
dando à viola caipira a dignidade de um instrumento universal, sem fronteiras rítmicas. De lá pra cá houve evolução, com Tião Carreiro e seus pagodes, Renato de Andrade com sua viola de concerto, Almir Sater e seus chamamés, e Roberto Corrêa a dar perfeição e técnica ao toque da viola (TORNEZE, 2010, p. 07).

O violeiro Almir Sater, além de cantor e compositor é um exímio instrumentista, e tem sido inspiração para inúmeros violeiros surgidos posteriormente ao seu trabalho. A afeição de Sater pelo campo e seu lugar é vastamente declarada e difundida nos meios de comunicação. Não havendo necessidade então, nesse caso, de fazer esse tipo de análise baseado nas letras de suas canções. Sater, que nasceu em Campo Grande Mato Grosso do Sul, em 14 de novembro de 1956, quando ali ainda era estado do Mato Grosso, declara constantemente sua paixão pelo lugar que ele fez dele, ao qual ele se afeiçoou, mais especificamente pelo Pantanal. Em entrevista à revista Viverde Natureza Sater (Apud KIRSNER, 2010, p. 6) relata:

\begin{abstract}
Eu conheço o Pantanal desde menino, sempre tive essa ligação muito forte com a natureza, sempre gostei de mato. Desde menino sempre quis morar em fazenda. Meu pai nunca gostou muito de mato, ele era ligado à bossa nova, barzinho, banquinho e violão e eu gostava de escutar moda de viola e ir para o meio do mato. Isso criava um certo conflito lá em casa. Eu insistia para o meu pai arrumar um pedaço de chão lá no Mato Grosso do Sul, e meu pai dizia: "Não! Quando você crescer, você arruma seu pedaço de chão, seu mato" E meu sonho então foi arrumar um mato. Eu conheci o Pantanal quando eu tinha mais ou menos 9 anos de idade, me apaixonei e sempre pensei em morar naquela região. Quando pude comprei meu pedaço de terra no Pantanal e fiz minha casa lá.
\end{abstract}

O elo afetivo de Sater pelo Pantanal é tamanho que, após gravar em 1982 o disco Doma, que foi em parceria com o rabequeiro Zé Gomes (com o qual Sater experimentaria ali suas primeiras produções com música instrumental), resolve voltar e explorar a identidade sonora do Pantanal. Começa então seu trabalho de campo com esse objetivo. Sousa (2005) relata:

\begin{abstract}
Era justamente neste universo instrumental da viola que Sater queria aprofundar. Em 1984 iniciou uma viagem musical pelo Pantanal mato-grossense junto com a Comitiva Esperança, que acompanhou por mais de mil quilômetros durante três meses em busca da essência musical do Pantaneiro. Encontrou isso e muito mais. A viagem, produzida pelo amigo e parceiro Paulo Simões, rendeu um documentário também chamado Comitiva Esperança. No ano seguinte lançou Almir Sater Instrumental, a síntese de seu mergulho no Pantanal, com chamamés, cururus, maxixes e arrastapés. Muito elogiado pela crítica, o disco teve uma continuação, o Instrumental II, mas somente em 1990 (Ibidem, p. 194-195).
\end{abstract}

Esse afeto pelo lugar parece ainda perdurar na vida de Sater, e, esse ambiente e ou contexto de convívio parece interferir diretamente na sua produção artística. O mesmo conta:

É difícil sair da fazenda. Sempre achamos que o tempo deu, mas nunca dá, a gente sai com vontade de ficar mais. Mesmo depois de ter passado nove meses direto aqui, quando fui embora a sensação era de tá deixando uma coisa muito preciosa pra trás. Aqui é pra quem gosta dessas coisas. Pra quem gosta de mato, de isolamento, pra 
quem tem paciência com mosquito. $\mathrm{O}$ isolamento é bom pra gente porque aqui não tem avenida, não tem bares, não tem nada. Quando os amigos, os parceiros, vêm pra cá, ficamos sentados, tocando. Para fazer música é bom, com o tempo de sobra. Ter certeza de que o cobrador não vai bater na porta. São coisas que contribuem para fazer música. Tem que estar de alma leve, feliz. Eu tenho de estar feliz pra compor. Tem gente que prefere estar na fossa, eu não sou assim (TELÓ; PIUNTI, 2015, p.95).

Renato Andrade, que é considerado um pioneiro nesse segmento musical que hibridiza o caipira e o erudito, o neocaipira, teve seus primeiros contatos com o instrumento e a cultura caipira ainda em Abaeté, Minas Gerais, cidade onde nasceu e morou parte de sua vida. Não encontramos até o momento relatos de Renato, onde esse declara diretamente sua afeição por sua terra natal, mas, sabe-se que uma das grandes frustrações dele e que o que "o incomodava era a falta de apoio da classe política de Abaeté, pois apesar de sempre divulgar a cidade não teve o reconhecimento que merecia" (CARDOSO, 2012, p. 21). Renato Andrade sempre fez questão de expor suas origens no interior mineiro, sempre enfatizando sua naturalidade.

O gosto pela viola caipira foi despertado pelas folias de reis de Abaeté que Renato costumava acompanhar na sua juventude. Em Abaeté, Renato também teve contato com outros violeiros que de certa forma o influenciaram, como por exemplo, um fazendeiro chamado Rafael do Capim Seco, o mais famoso violeiro da região, a quem Renato dedicou uma música no seu sexto disco. Outro violeiro que influenciou Renato foi um que gostava de tocar harmônicos na viola tentando imitar um realejo. Renato ao ouvir esses músicos foi criando seu estilo. Em 1965, o próprio Renato afirma que decidiu estudar viola com seriedade (CARDOSO, 2012, p.23).

Como indicativo, poderíamos fundamentar essa conexão afetiva de Renato com sua cidade, seu lugar, baseando-se no seu terceiro trabalho solo, $O$ violeiro e o grande sertão: a viola que vi e ouvi. Lançado pela gravadora Bemol, em 1984, o disco de vinil, no qual das 14 faixas, 13 são de autoria de Renato, "com composições que remetiam ao universo de Guimarães Rosa. [...] e na contracapa, Milton Nascimento escreveu, entusiasmado: 'Renato tem a alegria, o tormento, a ginga e a malícia dos que amam a terra' (NEPOMUCENO, 1999, p. 193)". A iniciativa de Renato com esse disco foi muito aclamada pela imprensa. O Jornal Estado de Minas publicou em 1984 uma matéria com a seguinte fala:

\footnotetext{
"O disco de Renato Andrade é puro Minas Gerais, é puro Renato, é puro coração da gente. Estamos diante de um dos discos mais importantes deste começo de ano. Vivo, autêntico, puro. Honesto e nosso até o último fio de cabelo". Essa pureza, segundo o texto, é consequência das raízes abaeteenses de Renato que fazem parte do sertão de Guimarães Rosa, das lendas e do folclore regional. Renato diz que nos dois primeiros discos ele procurou explorar o potencial da viola, e no terceiro, resolveu voltar às origens (CARDOSO, 2012, p.48).
}

Curiosamente, no ano em que Renato Andrade lança o seu primeiro disco solo, $A$ Fantástica Viola de Renato Andrade na Música Armorial Mineira, pela Chantecler, em 1977, principiam no universo violeirístico dois rapazes que viriam a se tornar adiante dois grandes nomes da música de viola. Além da viola caipira, curiosamente, nas histórias de vidas dos violeiros Roberto Corrêa e Paulo Freire podemos notar algumas coincidências. Ambos nasceram em 1957, tiveram o primeiro contato com instrumento em 1977, e, 
tiveram também seus casamentos realizados no ano de 1997 (SÁ, 2006). Os dois exímios violeiros, ambos iniciados musicalmente no violão, carregam um grande afeto pela música e cultura caipira e o ambiente onde essa é desenvolvida, além dos diálogos sonoros realizados da música destes com a música erudita. Devido a essa sonoridade requintada na viola produzida por esses violeiros no instrumento, autores como Nepomuceno (1999) os denominam como "neocaipiras".

Paulo Freire, natural de São Paulo, capital, antes violonista erudito. Mas, após ler Grande Sertão: Veredas, foi contagiado pela "magia" enaltecedora do sertão presente nos textos de Guimarães Rosa. A partir daí, Paulo Freire resolveu abandonar tudo, inclusive a faculdade de Jornalismo, a qual cursara à época, para estudar viola e conhecer de perto esse sertão. "A formação de Paulo Freire na viola caipira foi in loco, ou seja, aprendeu a tocar o instrumento com Manoel de Oliveira - sertanejo da região e outros grandes mestres das redondezas" (MELON, 2013, p. 08). Durante o dia, tinha a lida nos campos de Urucuia com seus mestres violeiros e a noite tinha as instruções no instrumento com os mesmos. Morava, comia, trabalhava, convivia e vivenciava em tempo integral com os mesmos a sua cultura. Relata:

E o que me levou a tocar viola, principalmente depois de ter lido Grande Sertão, do Guimarães Rosa, fui buscar a música do grande sertão. Então fui morar no sertão de Urucuia, onde se passa grande parte da trama do livro. Lá convivi com violeiros e as histórias todas, a natureza toda, e o diabo na rua, no meio do redemoinho, isso me levou à viola. Tenho certeza de que quanto mais eu toco, mais quero ler Grande sertão. [...] quando eu acabo de ler, me dá uma vontade de ir lá para Urucuia encontrar com o seu Manoel, meu mestre de viola, tomar banho de vereda (PAULO FREIRE apud TAUBKIN, 2008, p. 78).

encantamento por um lugar pode ser tanto um sentimento construído ao longo do tempo, vivenciando-o, quanto pode acontecer em um primeiro contato. Segundo Tuan (2013, p. 225):

Um homem pode se apaixonar à primeira vista por um lugar como também por uma mulher. [...] Uma experiência breve mas intensa é capaz de anular o passado, de modo que estamos dispostos a abandonar o lar pela terra prometida. Ainda mais curioso é o fato de que as pessoas podem desenvolver uma paixão por um tipo de meio ambiente sem terem tido contato direto com ele.

Paulo Freire até tentou arriscar ir novamente à Paris em 1982, para investir nos estudos de violão erudito, porém, agora, levaria na bagagem e no coração a sonoridade dos sertões de Urucuia, Minas Gerais. Ficou em Paris por dois anos, e numa de suas aulas de música clássica com o violonista Betho Davesaky, o músico Paulo Freire mostra a sonoridade de Urucuia para seu mestre que ao ouvir surpreso diz:

[...] "olha eu te ensino violão, mas o seu instrumento é a viola". [...] Ao voltar de Paris atuou em alguns grupos tocando viola e violão de 7 cordas. Mas a viola foi chamando, foi chamando e quando deu por si, estava novamente em Urucuia, motivado novamente pela literatura. Assim, 18 anos depois de conhecer a viola de Urucuia, aquela com a afinação Rio Abaixo, Paulo Freire gravou, enfim, seu primeiro disco de viola. (SOUSA, 2005, p. 212-213). 
Assim como outros violeiros que trabalham com músicas instrumentais, e que, apesar de não possuírem narrativas em letras de canções devido ao formato composicional de suas obras, esse tipo de declaração pode ser observada em entrevistas, livros e etc. Roberto Corrêa, nascido em Campina Verde, Minas Gerais, iniciou sua formação musical em Brasília, cidade a qual escolheu ${ }^{3}$ para viver e também para dar continuidade à sua carreira artística. E, apesar de não ser natural de capital brasileira, Roberto Corrêa desenvolveu um grande afeto por esta cidade, tanto que se sente às vezes até meio desnorteado quando fica certo tempo distante desse seu ambiente de convívio. Relata:

Não conheço nada de mar. Em 1987, resolvi tirar férias: fui passar 15 dias numa pousada no litoral do Nordeste. Como não levei viola, comecei a escrever poesia (não fazia letra de música até então). Mas não aguentei. Depois de nove dias, voltei, louco de vontade de caminhar na água mineral. Foi muita felicidade ao chegar lá. Pensei: esse aqui é o meu lugar, essa é a minha região (CORRÊA apud SÁ, 2006, p. 77-78).

Dentre esses escritos produzidos por Roberto Corrêa nessa ocasião, podemos destacar o poema Pacto, que foi incluído no disco Temperança, recitado acompanhado ao som da viola. Nos versos do mesmo fica bastante evidenciado o afeto e o sentimento de pertencimento ao seu território de convívio:

\author{
Pacto \\ Encerrado que eu era \\ No errado do existir \\ Livre, livre me tornei \\ Cerrado, cerrado meu \\ Quando em ti me transformei \\ O meu corpo é o teu chão \\ Tuas pedras, tuas águas \\ E minh'alma teus caminhos \\ Tua fauna, tua flora \\ Em ti minha vida está \\ Cerrado, cerrado meu \\ E em mim teu encanto mora \\ Eu, \\ Cerrado encordoado \\ Renascido e libertado \\ Pleno, vasto enfim \\ Vivo agora.
}

Usaremos como ponto de partida para essa análise a afirmação de Taubkin (2008, p. 21), na qual a mesma alega que "é difícil desvincular o instrumento do tocador, assim como separar sua música do universo onde ele vive. E que talvez por isso a gente sinta que a viola tem o dom particular de exprimir os sons do homem junto à natureza". Embasado nisso, analisaremos a relação desses dois violeiros com o espaço de referência onde seus trabalhos e obras se desenvolvem, e ainda a ligação pessoal e afetiva dos mesmos com esses lugares.

\footnotetext{
${ }^{3}$ Vale ressaltar que a capital brasileira é um lugar bastante estratégico no aspecto logístico. Talvez por estar situada numa região central e ser detentora de núcleos de administração política do país, possui uma certa agilidade em relação a deslocamentos para outras cidades do Brasil, e às vezes até para outros países, o que proporciona uma maior fluidez no cumprimento de agendas de apresentações.
} 
Apesar de tanto Paulo Freire e Roberto Corrêa não terem suas naturalidades em Urucuia, Minas Gerais e em Brasília, Distrito Federal respectivamente, ambos criaram um laço afetivo com esses lugares através da vivência e experienciação nos mesmos. Nos breves relatos desses violeiros aqui expostos, ficou bastante evidenciado um sentimento topofílico. Paulo Freire, uma vez que abandonou o curso de Jornalismo após ler e se encantar pelos "sertões" de Guimarães Rosa, deixou a entender que nesse momento se identificou com o mesmo. É bem visível que nessa ocasião houve um sentimento de pertencimento a cultura caipira da sua parte. Mesmo distante desse contexto sociocultural, resolveu abandonar tudo para vivenciá-lo. "Viveu rituais, crenças, lendas e festas que giram em torno do instrumento" (NEPOMUCENO, 1999, p. 38). Brota aí também um intenso sentimento de pertencimento a esse "sertão", o qual fez com que deixasse tudo que havia vivido antes para ir conhecer e viver o "sertão" com qual tanto se identificara. Conforme Cruz (2007, p. 27):

No que diz respeito à consciência de pertencimento a um lugar, a um território, essa é construída a partir das práticas e representações espaciais que envolvem ao mesmo tempo o domínio funcional-estratégico sobre um determinado espaço (finalidades) e a apropriação simbólico/expressiva do espaço (afinidades/afetividades).

Outro exemplo é o violeiro Fernando Deghi, que apesar de não ter encontrado até a ocasião dessa pesquisa, algo explícito sobre um sentimento de apego de Deghi com algum lugar e ou ambiente, em texto, onde o mesmo faz um comentário analítico sobre uma de suas composições, ele deixa evidenciada certa simpatia por ambientes onde se vivencia essa cultura caipira, conta:

\footnotetext{
"Viola e seus mistérios" e "Berceuse do sertão" foram inspiradas nas lembranças das minhas vivências e nas várias histórias contadas por violeiros, que envolveram a parte mística da viola, ou seja a magia do alvorecer, a força existente no meio das florestas, a magia do sertão que traz consigo a pureza de um modo de vida, enraizado no homem do campo. O que dói no coração é saber que muitos tiveram de abandonar suas terras e tradições. E hoje em dia lhes restam preservar simples lembranças do que outrora foi real e grandioso (DEGHI, 2001, p. 22).
}

Percebe-se também que há um processo de deslocamento e/ou mudança de ambiente entre esses violeiros. Nos casos analisados para esse trabalho, pode se notar também que em sua maioria não são advindos de classes econômicas mais baixas. $O$ violeiro Paulo Freire muda de Campina Verde, Minas Gerais para Brasília, Distrito Federal para estudar Física, Almir Sater deixa o Pantanal para morar no Rio de Janeiro, capital, e estudar Direito, Paulo Freire, que estudava Jornalismo e chegou a morar na França para estudar música erudita se desloca para Urucuia, Minas Gerais, Ivan Vilela natural de Itajubá, Minas Gerais vive hoje parte em São Paulo, capital e parte em Pindamonhangaba, São Paulo, Fernando Deghi apesar de nascido em Santo André, São Paulo, e residir maior parte da sua vida na região metropolitana de São Paulo, teve muito contato com seu sogro que tocava em bailes de roça, ou seja, a maior parte desses violeiros em alguma ocasião da vida tiveram vivências em zonas rurais e ou áreas interioranas da região centro-sul. Vale ressaltar também que grande parte desses têm vivências em folias e ou outras festas religiosas ligadas à cultura caipira. Ao mesmo tempo em que Paulo Freire explorava a magia dos "sertões" de Urucuia, Minas Gerais incitado pela literatura de Guimarães Rosa, trabalhando no campo ao dia com Seo 
Manelim em troca das lições de viola nos fins de tarde, Roberto Corrêa também percorria o interior do Brasil acompanhando folias e outras manifestações culturais que utilizavam viola - buscando a essência sonora e o conhecimento dos grandes mestres do instrumento oriundos das classes mais populares - na ocasião em que fazia pesquisas para a construção de seu método para viola. Corrêa conta que na elaboração de seu livro $A$ arte de pontear viola ele teve que criar uma simbologia própria para a viola, porque não havia antes (SÁ, 2006, p. 56). No entanto, a grafia musical parece não ter sido a única parte complexa desse trabalho. Enfatizamos aqui o moroso trabalho na busca por saberes do tocar viola em fontes de conhecimento isoladas Brasil adentro. A cultura popular em si, conforme alega Bosi (2002, p. 274) é um universo de escassez, dispõe de uma economia própria de coisas e signos, os quais tendem a permanecer os mesmos transmitindo-se de geração a geração, ainda que os significados e funções possam variar [...]. Por sua vez, Corrêa (2000) alega que:

Música tradicional é proveniente das manifestações de um povo; é recorte que fazemos da cultura popular. São funções musicais herdadas e transmitidas, de geração a geração, mantendo, mesmo com as naturais transformações de cada época, atributos essenciais da expressão do grupo (Ibidem, p.64).

A priori, Roberto Corrêa teve conhecimento da maioria dos ritmos ainda no início da década de $1980 \mathrm{com}$ a dupla Zé Mulato e Cassiano. Conforme o mesmo relata (apud MALAQUIAS, 2013, p.200): "Eu convivia muito com eles, [...] e com eles eu fui aprendendo os ritmos e conhecendo e sabendo das duplas, e indo atrás, comprando e conhecendo." Este seria então o início de uma intensa busca por práticas culturais, que até então estariam apartadas em meio aos "sertões" e/ou rincões brasileiros, e que perduraria até as décadas seguintes. Tendo como ponto culminante o livro "Arte de pontear viola" lançado por Roberto Corrêa no ano 2000, e conforme relata no mesmo:

\begin{abstract}
Quando me interessei por viola, seduzido pelo universo do instrumento, fui em busca do conhecimento que os violeiros antigos ainda detinham. Esta vivência formou-me como músico, muito além de conceitos e técnicas. Conheci outra dimensão do fazer musical: prática diferente na concepção, na função, na execução e no uso. Pude aprender sobre a lida do homem com o instrumento; a ancestralidade transmitida pelos toques; a força da tradição nos versos; os jeitos de entoar a voz, as clarezas e as sombras da alma do violeiro; e, principalmente, sobre os diferentes jeitos de o violeiro lidar com sua sina" (CORRÊA, 2000, p. 44-45).
\end{abstract}

Ivan Vilela, também relata, que seus alunos da graduação em viola caipira da Universidade de São Paulo são instigados a participar desses eventos para integralização da sua formação violeirística, uma metodologia que o mesmo denomina de "pedagogia do congado". Relata ainda que "esse método é um processo que os alunos aprendem por imitação - a tradição oral é isso - e. ao mesmo tempo, vão criando" (TAUBKIN, 2008, p. 105). Entendemos que, quando esse músico aponta acepções sobre a tradição oral, o mesmo está fazendo menção a um dos aspectos dessa, sobretudo, da dinâmica de ensino e aprendizagem de práticas musicais, não necessariamente em toda a sua abrangência. Ivan Vilela defende ainda que:

Um curso de viola deve ter recortes do mundo acadêmico quando se reporta à sistematização do material de ensino, mas tem que trazer muito do que vem da 
cultura popular, que é esse lado criativo, esse lado da soltura, e disso não abro mão de jeito algum. Os meus alunos mantêm um elo muito grande com a cultura popular, quer seja assistindo, quer seja participando de pesquisas, vendo congadas, viajando, vendo folias, eles estão muito próximos desse universo (Apud TAUBKIN, 2008, p. 88).

Percebe-se também, que, no universo violeirístico, de uma forma generalizada, existe uma preocupação de não se limitar a uma visão tecnicista e provocar um engessamento cultural. Há um cuidado por parte dos personagens envolvidos de não ignorar toda bagagem que o instrumento carrega seja técnica ou sociocultural-histórica. Isso, mesmo por parte daqueles que trabalham na busca de uma sistematização do ensino do instrumento.

Sater, Freire e Corrêa nasceram nos anos 1950 (época em que Guimarães Rosa escreveu Grande sertão: Veredas) e "viram" o Brasil se urbanizando por volta dos anos 1970 quando também há uma busca na música urbana pelo que é tradicional, rural, popular. Movimentos como a Tropicália de Caetano Veloso e Gilberto Gil e o Armorial liderado por Ariano Suassuna marcam essa busca de valorizar a cultura popular através da mescla cultural com o erudito e outras expressões artísticas distintas. Outra coincidência histórica se dá no fato de que, Renato Andrade, que é considerado o precursor desse segmento musical descrito por muitos autores como "neocaipira", no ano 1977 lança seu primeiro disco, ano este também no qual os violeiros Roberto Corrêa e Paulo Freire se principiam no universo da viola caipira (SÁ, 2006, p. 31).

\section{Considerações Finais}

sentimento topofílico desses violeiros pode ser percebido na forma de vida dos mesmos, nos seus escritos, pois além da música, grande parte desses possuem trabalhos literários, poesias, contam causos e outras narrativas acompanhadas ao som da viola. Isso ainda pode ser conferido em relatos de entrevistas. Quando Paulo Freire declara que "é só ler Guimarães Rosa que dá vontade de ir pra Urucuia", dá ainda mais ênfase a esse sentimento topofílico, o seu afeto pelo lugar. Já com Roberto Corrêa, além do sentimento topofílico que ficou evidenciado em sua narrativa, uma vez que chega a enfatizar que seu território vive através da sua música, da sua viola, quando descreve em seu poema: Eu, / Cerrado encordoado / Renascido e libertado / Pleno, vasto enfim / Vivo agora. Ficou evidenciado também em seu relato, um sentimento negativo a outro território com características distintas do seu. Sentimento esse que alguns autores denominam de topofobia. Segundo Relph (apud CIRQUEIRA, p. 40) definição de Topofobia está diretamente ligada a uma oposição ao conceito de topofilia, como "experiências de espaços, lugares e paisagens que são de algum modo desagradáveis ou induzem ansiedade e depressão".

Considerando que, topofilia, se dá em relação ao ambiente e também ao lugar, no caso dos violeiros neocaipiras, o afeto pode ocorrer pelo lugar de nascimento e ou de vivência, e, ainda em relação àqueles ligados ao meio urbano, mais especificamente das regiões metropolitanas, que se identificaram com esses lugares e ou ambientes mais rurais em alguma ocasião de suas vidas, ou, geograficamente falando, no decorrer de suas trajetórias socioespaciais. Em ambos os casos, essa afeição pelo lugar dos violeiros em questão não ultrapassa os limites de uma área geográfica específica, ou seja, mais especificamente, é manifestado em relação a uma propriedade rural, 
pequenas cidades, a uma paisagem de uma bioma específico - como é o caso de Roberto Corrêa em relação ao cerrado do planalto central, de Paulo Freire com os Sertões de Urucuia, e Almir Sater pelo pantanal sul-mato-grossense - que tende a não ultrapassar os limites do centro-sul do Brasil, com mais ênfase nas regiões interioranas.

\section{Referências}

BACHELARD, G. (1957). A poética do espaço. Tradução de Antônio de Pádua Danesi. São Paulo: Martins Fontes, 2008. 2. ed. 242p.

BORGES, T. Topofilia. Joelho: Revista de Cultura Arquitectónica. № 04 (2013).

BOSI, Alfredo. Homenagem a mestre Xidieh. In: Literatura e resistência. São Paulo: Companhia das Letras, 2002. p. 270-282.

BRITO, D. S. Negociações de um Sedutor: trajetória e obra do compositor Goiá no meio artístico sertanejo (1954-1981). 2009. 175f. Dissertação (Mestrado em História) Universidade Federal de Uberlândia. 2009.

CÂNDIDO, A. Os Parceiros do Rio Bonito: Estudo sobre o caipira paulista e a transformação dos seus meios de vida. Ouro sobre Azul, Rio de Janeiro: 2010. 11 a ed.

CARDOSO, B. A. A viola embaixatriz de Renato Andrade: contextualização das turnês patrocinadas pela Ditadura Militar e ponderações sobre a face caipira do violeiro. 2012. 109f. Dissertação (mestrado) - Escola de Música, Universidade Federal de Minas Gerais, Belo Horizonte. 2012.

CASTROGIOVANNI, A. C. Para entender a necessidade de práticas prazerosas no ensino de Geografia na pós-modernidade. In:_REGO, Nelson; CASTROGIOVANNI, A. C; KAERCHER, N. A. (Org.) Geografia: práticas pedagógicas para o ensino médio. Porto Alegre: Artmed, 2007, p. 35-48.

CIRQUEIRA, Diogo Marçal. Entre o corpo e a teoria: a questão étnico-racial na obra e trajetória socioespacial de Milton Santos. 2010.161 f. Dissertação (Mestrado) - Instituto de Estudos Socioambientais, Universidade Federal de Goiás, Goiânia. 2010.

CONTIER, A. D. O teatro popular: Rio de Janeiro, a cidade polifônica (1930-1945). Cadernos de Pós-graduação em Educação, Arte e História da Cultura (São Paulo), São Paulo, v. 3, n.1, 2003.

CORRÊA, R. N. A arte de pontear viola. Brasília: Viola Corrêa, 2000.

CRUZ, V. C. Itinerários teóricos sobre a relação entre território e identidade. In: BEZERRA, A. C.A. et. Al. (Orgs.). Itinerários Geográficos. Niterói. EdUFF, 2007.p,13-35.

DEGHI, F. Viola brasileira e suas possibilidades. São Bernardo do Campo: Violeiro Andante, 2001. 168p.

DOZENA, A. O Papel da Corporeidade na Mediação entre a Música e o Território. In: DOZENA, A. (Org.). Geografia e Música: Diálogos. 1. Ed. NATAL: EDUFRN, 2016. 399p.

GÓMEZ, G. M. Razón y pasión del espacio y el territorio. In: . Et. Al. (Orgs.) Espacio y territorios: Razón, pasión y imaginarios. Bogotá: Unobiblos, 2001. P, 15-32.

KIRSNER, P. Almir Sater cidadão do mato. Revista Viverde Natureza | Edição 16 | junho/julho 2010. Ano 4 • Edição 16 • junho/julho de 2010. p. 6-8. 
MALAQUIAS, D. R. O pagode de viola de Tião Carreiro: configurações estilísticas, importância e influências no universo da música violeirística brasileira. 2013. 270 f. Dissertação (Mestrado), Escola de Música e Artes Cênicas, Universidade Federal de Goiás, Goiânia, 2013.

MELON, C. A. Transformação da música sertaneja do século XX: o jogo da contenção e absorção. In: XXVII Simpósio Nacional de História, 2013, Natal. XXVII Simpósio Nacional de História, 2013.

NEPOMUCENO, R. Música caipira: da roça ao rodeio. São Paulo: Editora 34, 1999.

OLIVEIRA, L. O sentido de lugar. In: MARANDOLA JR. et al. Qual o Espaço do Lugar? Geografia, Epistemologia, Fenomenologia. São Paulo: Perspectiva, 2012.

PIMENTEL, S. V. O chão é o limite: a festa de peão boiadeiro e a domesticação do sertão. Goiânia: Editora da UFG, 1997. 308p.

SÁ, S. de. Roberto Corrêa: caipira extremoso. Brasília: Ed. do Autor, 2006. 120p.

SATER, A. Almir Sater cidadão do mato. [Editorial]. Revista Viverde Natureza, Edição 16, Ano 4, jun./jul., 2010.

SOUSA, W. Moda inviolada - Uma história da música caipira. São Paulo: Quiron Comunicação \& Conteúdo, 2005. 250 p.

TAUBKIN, Myriam. Violeiros do Brasil. São Paulo: Ed. Myriam Taubkin, 2008.

TELÓ, M; PIUNTI, A. Bem sertanejo: a história da música que conquistou o Brasil. 1. ed. - São Paulo: Planeta, 2015.

TORNEZE, R. Viola caipira instrumental: 42 estudos progressivos. São Paulo: Irmãos Vitalle, 2011. 48p.

TUAN, Yi-Fu. Espaço e lugar: a perspectiva da experiência. Londrina: EdUEL, 2013.

TUAN, Yi-Fu. Topofilia: um estudo da percepção, atitudes e valores do meio ambiente. São Paulo: Difel, 1980. 